\title{
Development Of Guided Discovery Learning Mathematics For Student's Reasoning Ability Class X SMA/MA
}

\author{
$1^{\text {st }}$ Zulmen Suhendri \\ Department of Mathematics \\ Universitas Negeri Padang \\ Padang, Indonesia \\ zulmen.suhendri79@gmail.com
}

\author{
$2^{\text {nd }}$ Yerizon \\ Department of Mathematics \\ Universitas Negeri Padang \\ Padang, Indonesia
}

\author{
$3^{\text {rd }}$ Ratnawulan \\ Department of Mathematics \\ Universitas Negeri Padang \\ Padang, Indonesia
}

\begin{abstract}
The mathematical ability of Indonesian students is still very low compared to other countries. One alternative to overcome the problem is by creating learning instructional that allows students to learn well. Most of learning instructional developed today do not accommodate the students learning styles especially in schools that have classified students based on multiple ability. The dominant ability in the classroom is reasoning ability. The purpose of this research is to produce a mathematics learning instructional based on Discovery Learning approach that are valid. These instructional are developed using a development model adapted from the plom model. The development process of these instructional consists of 3 phase: Front-end preliminary research result, we obtain that the reasoning ability student learning outcomes is low. Teachers and student desperately need learning instructional with simple language and can guided students to understand the subjectmatter.
\end{abstract}

Keywords-Guided Discovery, Reasoning Ability, trigonometry

\section{INTRODUCTION}

The Mathematical ability of Indonesian students is still low. Result of Trends in International Mathematics and Science Study (TIMSS) 2015 Shows that the average score of eighth grade Indonesian students only 397 out of 500 and ranked $44^{\text {th }}$ among 49 countries (Mullis,2016). This result is a slightly increase compared to the 2011 TIMSS results, i.e. an average score of 386 (ranked $39^{\text {th }}$ out of 43 countries). On the other hand, the result of the Program for International Student Assessment (PISA) 2015 shows that Indonesia ranked $63^{\text {rd }}$ among 70 countries with the average score is 386 (OECD, 2016). This is a slight improvement from PISA 2012 result (ranked $64^{\text {th }}$ of 65 countries and average score 375). The result also reveals thet $68.6 \%$ of students'performance is below the second level and only $0.7 \%$ of them reach level five and six. It shows that the learning of mathematics in the class is not optimal yet. According to Organizational for Economic Co-operation and Development (OECD), students below the second level are considered not to be able to function effectively in the life of the $21^{\text {st }}$ century.

The purpose of mathematics subjects according to permendiknas no 58 of 2014 are: Using reasoning on the nature, performing mathematical manipulations both in simplification, as well as analyzing the existing components in problem solving in the context of mathematics as well as outside mathematics (real life, science, and technology ability to understand problems, build mathematical models, complete models and interpret the solutions obtained in order to solve problems in everyday life (real world).

Based on the objectives of the mathematics lesson above, one of the abilities that must be mastered by students is the ability of mathematical reasoning. Mathematical reasoning is a logical process of thinking. That is, learners are able to consider about the bad, the power of thought or the activity of thinking. Paranaran is a high-level mathematical thinking process to draw conclusions based on a statement called the premise or antecedent, while the result of a new statement which is conclusions are called conclusions or consequences.

Based on the observations made in some high school level obtained a picture of learning devices used by teachers. The devices used in schools have not been practical in terms of content and presentation. Then, the ability of students' mathematical reasoning is still low. This is demonstrated by the analysis of students' mathematical reasoning abilities. Giving questions of mathematical reasoning skills performed in two different schools. The results are seen in indicating the average score of each indicator is not yet ideal. It also shows the students' mathematical reasoning abilities in the two schools represented by the three indicators are experiencing problems. Because the average score that must be obtained by students for each indicator is not maximally that is 4 . Classically, as much as $75 \%$ of students have reasoning ability is still low. The guided discovery-based learning device in which there is instruction aimed at guiding students to find a general concept and principle. Students are encouraged to think for themselves, analyze themselves so that they can find general concepts and principles based on the materials or data that have been provided in the teaching materials.

The advantages of this guided discovery method, can encourage active learners in learning activities. because he thinks and uses the ability to find the end result. Selfdiscovery raises a sense of satisfaction. This inner satisfaction encourages the discovery again until the interest of learning increases. This method trains students to learn more by themselves. Devices developed in the form of RPP, LKPD, and Intrumen assessment. In accordance with Government Regulation No. 65 of 2013 on Standard Process of Primary and Secondary Education which implies that teachers as educators to develop the Lesson Plans (RPP). Thus, every educator is obliged to develop learning tools 
including RPP, LKPD and evaluation tools that are complete and systematic in order that the learning takes place interactively, inspiration, fun, so as to motivate learners during the learning process. Guided discovery method according to Sabri (2005: 12) is a way of delivering mathematical topics so that the learning process allows learners to find their own mathematical patterns or structures through a series of past experiences that are in the guidance of the teacher. From the above opinion, it can be concluded that guided discovery method is a way of delivering the material by involving learners to find their own concepts or ideas of mathematics through science gained previously in the guidance of the teacher concerned. In this method, the teacher acts as a facilitator who helps learners to use previously acquired concepts, ideas and mathematical skills to discover new knowledge. Guided discovery methods can be done individually or in groups.

According to Markaban (2006: 16) the learning steps with guided discovery are as follows:

a. Formulate problems to be provided to students with sufficient data.

b. From the data provided by the teacher, the students prepare, process, organize, and analyze the data. In this case teacher guidance can be given to what extent is neededonly.

c. Students construct conjectures (forecasts) from the results of the analysis it does.

d. When deemed necessary, the conjecture that has been made by the above students is examined by the teacher.

e. If it has been obtained certainty about the truth of the conjecture, then the verbalization of conjecture should also be directed to the students to arrange it.

f. After students find what they are looking for, the teacher should provide additional exercises or questions to check whether the findings are true.

g. Teachers provide additional questions to test learners' understanding.

In Permendiknas number 41 of 2007 on Process Standards it is explained that the Learning Implementation Plan (RPP) is a plan that describes the procedure and organizing the learning to achieve one basic competency set forth in the Content Standards and has been described in the syllabus. In accordance with the Minister of National Education it is explained that the RPP is derived from the syllabus to direct the learning activities of learners in order to achieve KD. Sudjana, (1997: 134) "Sheet activities of learners contain subject matter that must be mastered students. The composition of the material in accordance with the learning objectives to be achieved, prepared step by step so as to facilitate learners learn. "LKPD is a sheet of paper that contains activities to obtain concepts and information as well as questions that must be answered by learners. In addition, LKPD should be written in a simple and easy to understand sentences by learners.

Things that should be contained in LKPD, namely:

a. Learners' instructions on the topics covered, general direction and time available.

b. Objectives lessons that students are expected to gain after learners learn with the LKPD.

c. Lesson tools used.

d. Specific instructions on the steps of activities undertaken by learners and provided in detail and interspersed with the execution of activities.
This LKPD discovery contains problems, examples of questions, exercises and assessments. The stages in the LKPD based guided discovery are described as follows: In the early stages of this LKPD learners are given problems related to daily life in accordance with the material being studied. Learners are given steps in constructing their understanding such as the formulation of the problem, then learners organize, process, organize, analyze so that learners can understand and find the concept and solve the problems that adadalam material being studied. LKPD is designed to be done in groups by learners. So that after the learners complete the activities in LKPD with the group of learners are asked to present the results obtained in the classroom. This activity is expected to further strengthen the concept of learners because there are various opinions and input given by other groups. This LKPD contains exercises in the form of problems of conceptual comprehension that students can do in school. This exercise aims to learners can apply the concepts that have been obtained on the subject matter that day and so that learners better understand the material learned.

At the end of the LKPD section the learner is also asked to make a conclusion with his own words on the material he has learned, it is intended to provide a sense of satisfaction and pride in the learners that he is able to master the material well studied. LKPD based guided discovery is designed using sentences that are easily understood by learners. Shurter and Pierce (in Dahlan, 2004, p.21) state that reasoning is a process of achieving logical conclusions based on relevant facts and sources, transforming given in a certain order to reach a conclusion. The indicators of mathematical reasoning ability used in this research are: (1) Present mathematical statement in oral, written, drawing, and diagram (Communication) (2) Proposing allegation (3) Conducting mathematical manipulation (4) Finding pattern or characteristic of mathematical symptom make generalizations. The scoring criteria for mathematical reasoning tests using modified scanning holistic scale scanning of Cai, Lane and Jakabcin as indicated in Table 1.

\section{TABLE I. STUDENT'S RESPONSE TO PROBLEMS}

\begin{tabular}{|l|l|}
\hline Student's Response to Problems. & Scor \\
\hline $\begin{array}{l}\text { No answer / answer does not match the question / not } \\
\text { correct }\end{array}$ & 1 \\
\hline Only part of the question is answered correctly & 2 \\
\hline $\begin{array}{l}\text { Almost all aspects of the question are answered } \\
\text { correctly }\end{array}$ & 3 \\
\hline $\begin{array}{l}\text { All aspects of the questions answered completely / } \\
\text { clearly and correctly }\end{array}$ & 4 \\
\hline
\end{tabular}

\section{METHODS}

The type of research conducted is research and development (research and development), which aims to produce a valid learning tool. Model of development in this research is Model Plomp. This model was developed by TjeerdPlomp. The Plomp model consists of three stages: preliminary research, development or prototyping phase and assessment phase.

In the prototype development phase and assessment phase will be tested and revised based on formative evaluation. Formative evaluation is an assessment of the 
strengths and weaknesses of the product in the development stage, with the aim of reviewing the product to improve validity. Formative evaluation will be illustrated in the figure.

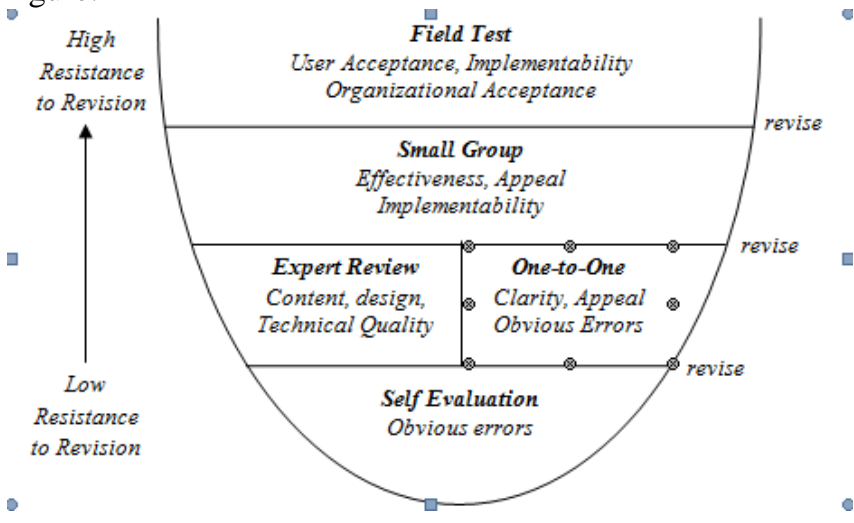

Fig. 1. Example The layers of formative evaluation of the Plomp development model (Source: Tessmer, 1993 in Plomp and Nieveen, 2013: 36)

\section{RESULT AND DISCUSSION}

\section{A. Preliminary Research Results}

Define This stage is to define and define the requirements required in the development of guided learning-based mathematical learning tools on trigonometric material.
a. Needs analysis
b. Analysis of learners
c. Curriculum Analysis.
d. Analyze concepts / materials.

\section{B. Results Phase Manufacture and Development Prototype (Prototyping Phase)}

The purpose of the phase prototyping phase is to design a project-based mathematical learning tool that contains the material in accordance with the basic competencies and learning objectives that have been determined. The design process of this device are: Designing RPP, LKPD and Assessment Instrument. The device is designed according to the time allocation listed in the syllabus.

\section{Assessment Phase (Assessment Phase)}

Design results at this stage produce prototype 1 , then self-evaluation and expert or expert judgment are performed. Guided discovery RPP validated by 5 experts, namely 3 lecturers mamatika, 1 lecturer of educational technology and 1 lecturer Indonesian language. The result of RPP validation based on guided discovery is presented in Table 2 .

TABLE II. RESULT OF RPP VALIDATION RECAPITULATION BASED ON TRIGONOMETRY MATERIAL GUIDED DISCOVERY

\begin{tabular}{|c|c|c|c|c|c|c|c|}
\hline \multirow{2}{*}{ Rated aspect } & \multicolumn{5}{|c|}{ Validator } & \multirow{2}{*}{$\begin{array}{l}\text { Ave } \\
\text { rage }\end{array}$} & \multirow{2}{*}{ Criteria } \\
\hline & 1 & 2 & 3 & 4 & 5 & & \\
\hline $\begin{array}{c}\text { RPP } \\
\text { Components }\end{array}$ & 4,00 & 3,80 & 3,80 & 4,00 & - & 3,90 & $\begin{array}{l}\text { Very } \\
\text { valid }\end{array}$ \\
\hline $\begin{array}{l}\text { Learning } \\
\text { Activities }\end{array}$ & 4,00 & 3,40 & 3,80 & 3,80 & - & 3,75 & $\begin{array}{l}\text { Very } \\
\text { valid }\end{array}$ \\
\hline $\begin{array}{c}\text { Language and } \\
\text { legibility }\end{array}$ & 4,00 & 3,67 & 4,00 & 4,00 & 4,00 & 3,93 & $\begin{array}{l}\text { Very } \\
\text { valid }\end{array}$ \\
\hline Average & 4,00 & 3,62 & 3,87 & 3,93 & 4,00 & 3,88 & $\begin{array}{l}\text { Very } \\
\text { valid }\end{array}$ \\
\hline
\end{tabular}

Based on the Table, it can be concluded that the overall RPP-based guided discovery has met the criteria is very valid with the average index of the validity and 3.88 .

Validation LKPD conducted by 5 validators consisting of 3 lecturers of mathematics education, 1 lecturer of educational technology and 1 lecturer of Indonesian language. LKPD validation results based on discovery guided in all aspects can be seen in Table 3 .

TABLE III. RECAPITULATION RESULT OF LKPD BASED ON INVENTION BASED ON TRIGONOMETRY MATERIAL

\begin{tabular}{|c|c|c|c|c|c|c|c|}
\hline \multirow{2}{*}{ Rated aspect } & \multicolumn{5}{|c|}{ Validator } & \multirow{2}{*}{$\begin{array}{c}\text { Aver } \\
\text { age }\end{array}$} & \multirow{2}{*}{ Criteria } \\
\hline & 1 & 2 & 3 & 4 & 5 & & \\
\hline Aim & 4,00 & 4,00 & 3,67 & 4,00 & - & 3,92 & $\begin{array}{l}\text { Very } \\
\text { Valid }\end{array}$ \\
\hline Rational & 4,00 & 3,50 & 4,00 & 4,00 & - & 3,87 & $\begin{array}{c}\text { Very } \\
\text { Valid }\end{array}$ \\
\hline contens LKPD & 4,00 & 3,50 & 3,75 & 3,87 & - & 3,78 & $\begin{array}{l}\text { Very } \\
\text { Valid }\end{array}$ \\
\hline Characteristics & 4,00 & 3,86 & 3,86 & 4,00 & - & 3,93 & $\begin{array}{l}\text { Very } \\
\text { Valid }\end{array}$ \\
\hline $\begin{array}{l}\text { Language and } \\
\text { legibility }\end{array}$ & 4,00 & 4,00 & 3,75 & 3,87 & 4,00 & 3,90 & $\begin{array}{l}\text { Very } \\
\text { Valid }\end{array}$ \\
\hline LKS Display & 4,00 & 3,60 & 4,00 & 4,00 & - & 3,90 & $\begin{array}{l}\text { Very } \\
\text { Valid }\end{array}$ \\
\hline Average & 4,00 & 3,74 & 3,83 & 3,96 & 4,00 & 3,91 & $\begin{array}{l}\text { Very } \\
\text { Valid }\end{array}$ \\
\hline
\end{tabular}

Based on the table, it is seen that in general the validity of the objective, rational, content, characteristic, language and appearance aspects of LKPD based on guided discovery has met the criterion very valid with average validity as a whole is 3.91 for trigonometric material. Graphical tabulation questionnaire validation of guided discovery based learning device can be seen in the figure

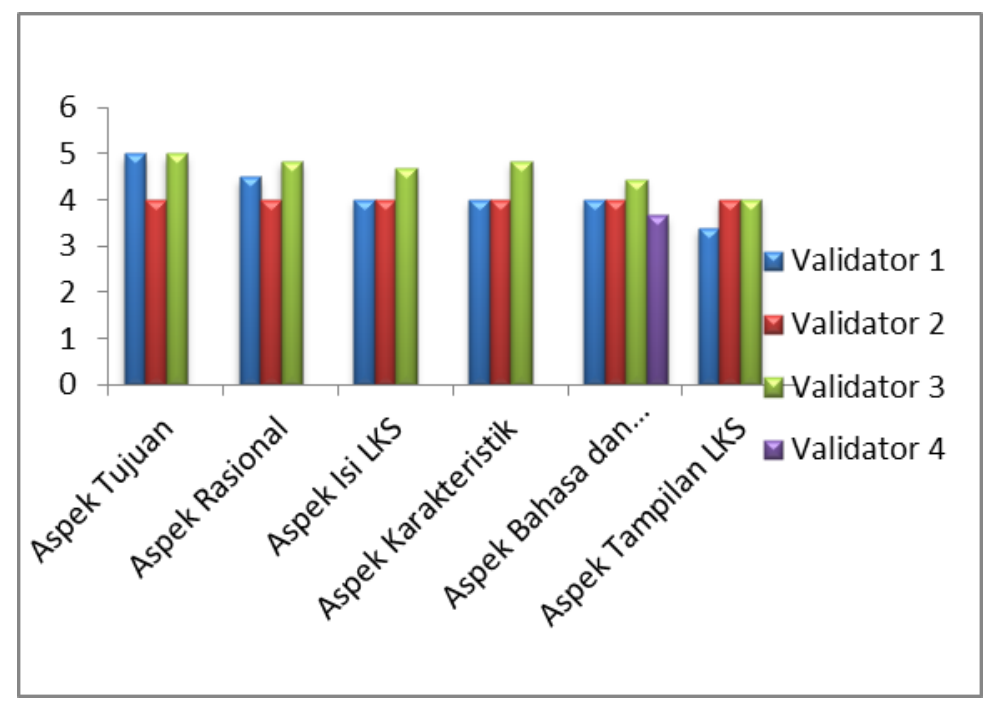

Fig. 2. Graph of tabulation results Validation Sheet Validation of Guided Learning Based Learning Device 


\section{CONCLUSION}

a. The process of designing discovery-based mathematical learning tools guided on trigonometric material begins by investigating initial problems, analyzing the needs of students as well as performing syllabus analysis.

b. The discovery-based mathematics learning device is guided on the categorized valid spatial construct material.

\section{REFERENCES}

[1] Achera. Luzviminda, "The Effect Of Group Guided Discovery Approach On Theperformance Of Students In Geometry", International Journal of Multidisciplinary Research and Modern Education (IJMRME), 1(2), 2015.
[2] Akani. Omiko, "Effect of Guided Discovery Method of Instruction And Students' Achievement in Chemistry at the Secondary School Level in Nigeria", International Journal of Scientific Research and Education, 5(2): 6226-6234, 2017.

[3] Akinbobola. Akinyemi Olufunminiyi dan Folashade Afolabi, "Constructivist Practices Through Guided Discovery Approach: The Effect On Students' Cognitive Achievements In Nigerian Senior Secondary School Physics", Bulgarian Journal of Science and Education Policy (BJSEP), 3 (2), 2009.

[4] Asuai Nelson Chukwuyenum, "Impact of Critical thinking on Performance in Mathematics among Senior Secondary School Students in Lagos State", IOSR Jurnal Penelitian \& Metode dalam Pendidikan (IOSR-JRME), 3 (5): 18-25, 2013.

[5] Çalgin. Zeliha dan Mustafa Koç., "The Effect of WebQuestSupported Mathematics Instruction on Sixth Grade Students' Critical Thinking Skills", Necatibey Faculty of Education Electronic Journal of Science and Mathematics Education, 11 (1):. 1-20, 2017.

[6] Depdiknas, Kurikulum Tingkat Satuan Pendidikan SMP, Jakarta: Depdiknas, 2006. 